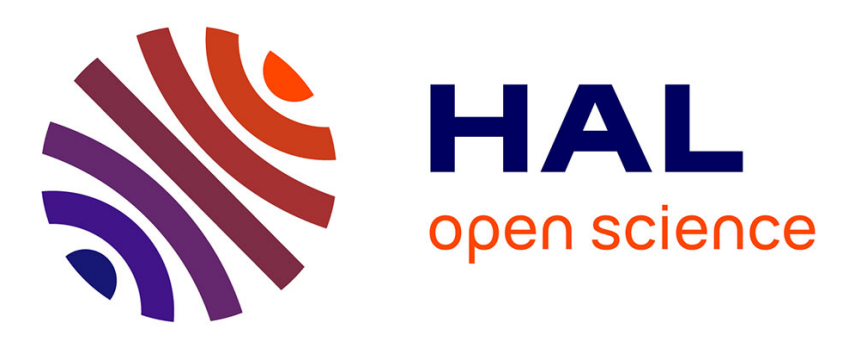

\title{
Weed dispersal by farming at various spatial scales. A review
}

\author{
Sandrine Petit, Audrey Alignier, Nathalie Colbach, Alexandre Joannon, \\ Didier Cour, Claudine Thenail
}

\section{- To cite this version:}

Sandrine Petit, Audrey Alignier, Nathalie Colbach, Alexandre Joannon, Didier Cœur, et al.. Weed dispersal by farming at various spatial scales. A review. Agronomy for Sustainable Development, 2012, 33 (1), pp.205-217. 10.1007/s13593-012-0095-8 . hal-01201381

\section{HAL Id: hal-01201381 \\ https://hal.science/hal-01201381}

Submitted on 17 Sep 2015

HAL is a multi-disciplinary open access archive for the deposit and dissemination of scientific research documents, whether they are published or not. The documents may come from teaching and research institutions in France or abroad, or from public or private research centers.
L'archive ouverte pluridisciplinaire HAL, est destinée au dépôt et à la diffusion de documents scientifiques de niveau recherche, publiés ou non, émanant des établissements d'enseignement et de recherche français ou étrangers, des laboratoires publics ou privés. 


\title{
Weed dispersal by farming at various spatial scales. A review
}

\author{
Sandrine Petit • Audrey Alignier • Nathalie Colbach • \\ Alexandre Joannon • Didier Le Cour • Claudine Thenail
}

Accepted: 27 April 2012 / Published online: 15 June 2012

(C) INRA and Springer-Verlag, France 2012

\begin{abstract}
Reducing pesticide use in agriculture is necessary to preserve natural resources. However, pest control without pesticides is a challenging issue. In particular, weed infestation may cause severe losses of crop yield. Weeds have been traditionally managed solely at the field level. However, larger scales must be considered because invasive and herbicide-tolerant weeds are spreading over larger scales. This review discusses three spatial scales at which agricultural management might affect the dispersal of weeds and, in turn, their distribution and abundance in agricultural fields. The main points are: (1) at the field level, crop and margin management impact mass effect, i.e., local exchanges between the field margin and the cultivated field; (2) at the farm level crop allocation, the management of field boundaries and agricultural circulation in the farm strongly impact the intensity and direction of weed dispersal; and (3) at the landscape level, the spatial farms distribution controls the distribution of weed habitat and, in turn, landscape species pool and long-distance
\end{abstract}

S. Petit $(\bowtie) \cdot$ A. Alignier $\cdot N$. Colbach

INRA, UMR 1347, Agroécologie ECOLDUR,

21000 Dijon Cedex, France

e-mail: sapetit@dijon.inra.fr

A. Joannon $\cdot$ D. Le Cœur $\cdot$ C. Thenail

INRA, UR 980, SAD-Paysage,

35000 Rennes, France

D. Le Cœur

AGROCAMPUS OUEST,

35000 Rennes, France weed dispersal. We conclude that weed dispersal is driven by agricultural management at multiple scales. Weed scientists should thus extend their view on weed dispersal from within-field scales to among-field and landscape scales.

Keywords Weed management $\cdot$ Field boundary $\cdot$ Agricultural circulation $\cdot$ Land use allocation $\cdot$ Connectivity $\cdot$ Concerted management

\section{Introduction}

There is increasing evidence that land management options have an impact on the functioning of the agro-ecosystem over a wide range of spatial and managerial scales encompassing the field, the farm, and the landscape level (Firbank et al. 2008). There is obviously little consensus as to an "optimum" scale for management as economically important biodiversity (species to be harvested, pest species, natural enemies) vary in their ecological requirements and respond to their environment at different spatial scales (Aviron et al. 2009; Gabriel et al. 2010). Among the taxa requiring effective management within agro-ecosystems, arable weeds are an important target, as they are a key group both in terms of arable crop productivity and farmland biodiversity (Petit et al. 2010). Identifying effective weed management options is crucial as weeds limit crop productivity by competing with the crop for available sunlight, water, and nutrients (Bastiaans et al. 2000; Oerke 2006). Weeds are also at the basis of the agro-ecosystem food web 
and as such support many taxa, e.g., invertebrates (Bohan et al. 2007), farmland birds (Gibbons et al. 2006).

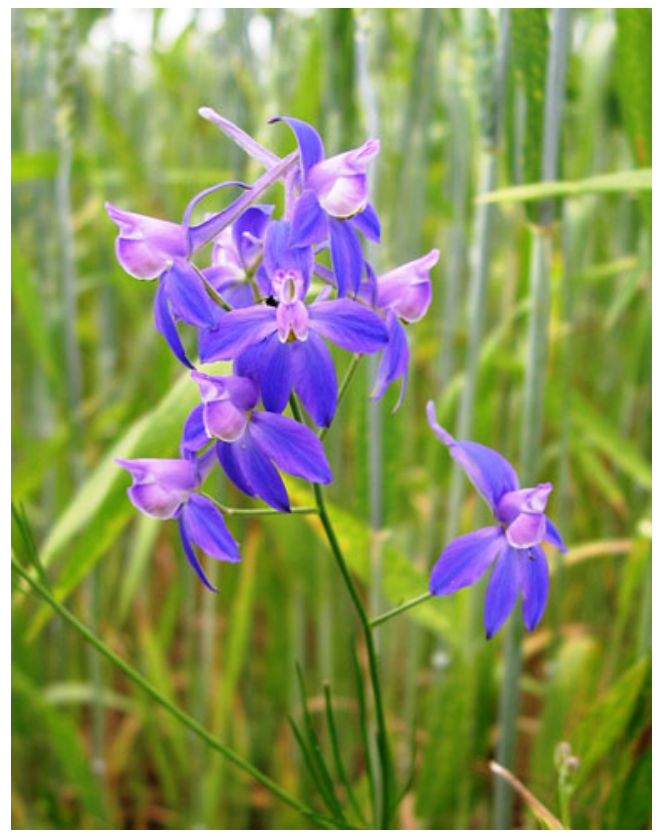

Fig. 1 Delphinium consolida

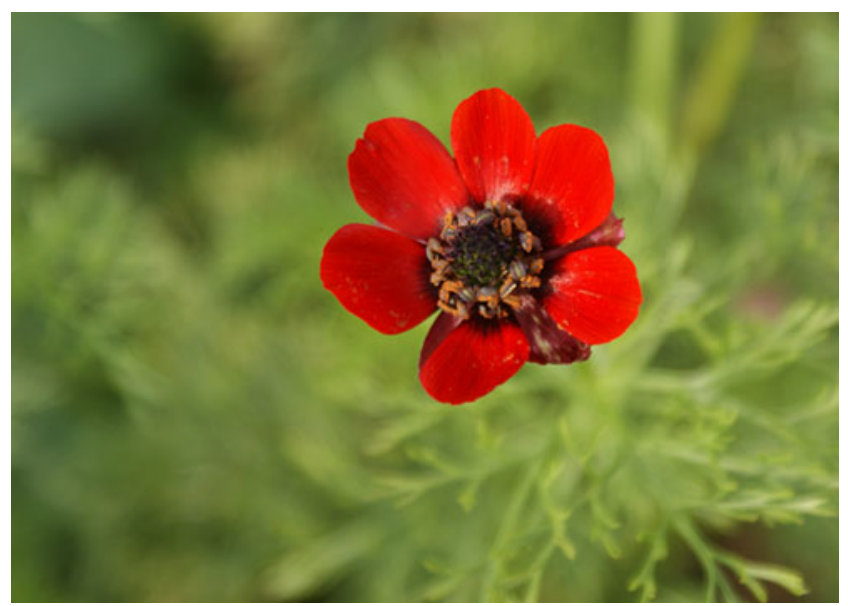

Fig. 2 Adonis annua

Weed communities are strongly shaped by the management applied within individual fields. Crop type (Hallgren et al. 1999; Fried et al. 2009a), preceding crop (Fried et al. 2008), sowing date (Gunton et al. 2011), crop succession (Bohan et al. 2011), tillage systems (Mayor and Dessaint 1998; Cardina et al. 2002), levels of fertilizers, and herbicide inputs (Dieleman and Mortensen 1999; Storkey et al. 2010) have been recognized to account for variations in weed assemblages. Yet, some problematic weed management issues require weed scientists to consider weed dispersal within and among different fields at the landscape level.
These issues include the spread of invasive annual weed species such as the common ragweed (Chauvel et al. 2006), the spread of herbicide resistance in problematic weed species (Dauer et al. 2009; Délye et al. 2010), and the issue of contamination by gene flow in the context of genetically modified (GM) crops (Colbach 2009; Le Bail et al. 2010). The conservation of (rare) arable weeds also raises concern, given the drastic decline of arable weeds over the last decades, described in several ecological diachronic studies carried out across Europe (e.g., Andreasen et al. 1996; Hyvonen and HuuselaVeistola 2008; Fried et al. 2009b). These management issues have revealed the current gap in knowledge as to the geographical extent, the intensity, and the role of dispersal in the dynamics of weed communities. More to the point, it is unclear whether or not the spatial arrangement of management decisions at different scales may potentially represent a lever to hinder or favor weed spread and persistence in agro-ecosystems. It has often been assumed that the large-scale spatial dynamics of weeds is so strongly dominated by local processes occurring in the field (Freckleton and Watkinson 2002) that the consideration of factors operating at larger spatial scales, e.g., dispersal capacity, habitat availability, and connectivity (Ehrlén and Eriksson 2003) is not required. On the other hand, an increasing number of empirical studies suggest that some large-scale factors (i.e., acting at scales beyond the field) strongly impact weed diversity both at local and regional scales (Gabriel et al. 2005; Poggio et al. 2010).

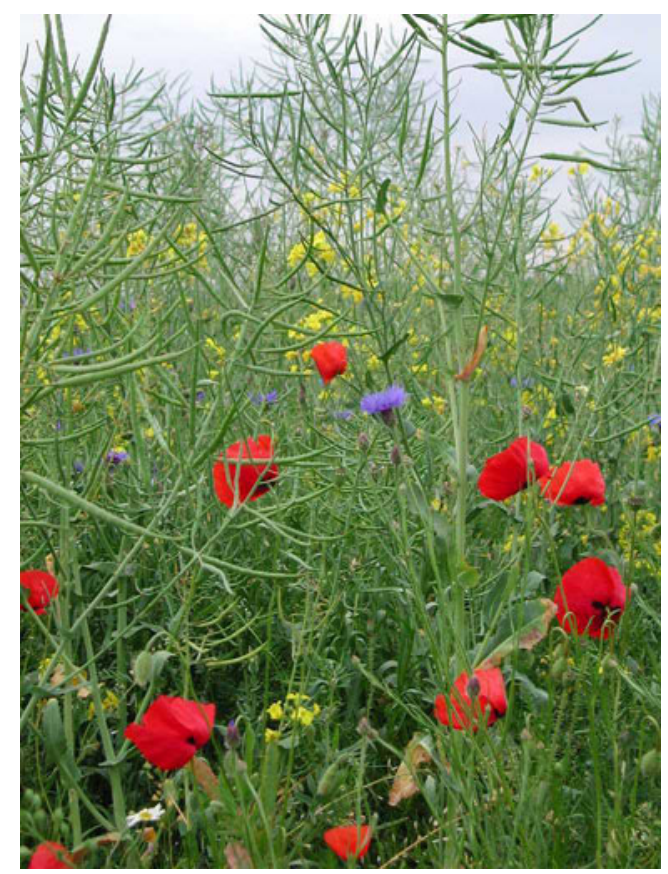

Fig. 3 Papaver rhoeas and Centaurea cyanus in oilseed rape 


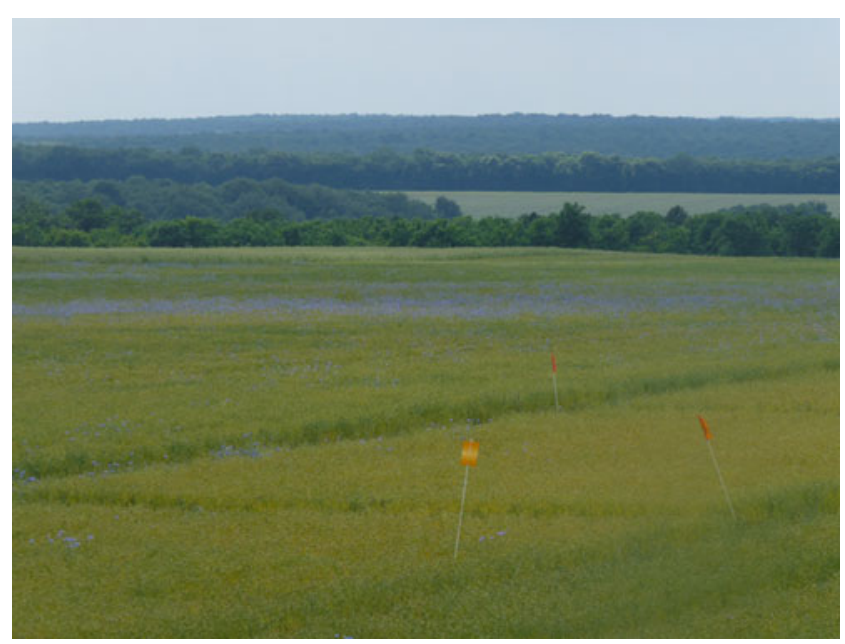

Fig. 4 Patches of Centaurea cyanus within a crop

We consider here three spatial scales at which agricultural management might affect the dispersal of weeds and therefore their distribution and abundance in agricultural fields: (a) the local management of the crop and its boundaries and its impact on weed seed movements within and between the two habitats (b) the activities carried out at the farm level and their impact on weed seed movements and weed distribution at the farm level, and (c) the shaping of landscape spatial patterns by agricultural production and its effect on long distance weed dispersal. At each scale, a comprehensive but nonexhaustive analysis of the impact of different agricultural activities on weed dispersal was carried out to assess the importance of management at each scale on the large-scale spatial dynamics of weeds.

\section{Dispersal constraints at the field level}

Field management includes the succession of agricultural practices that are carried out in the field (crop) as well as practices devoted to the boundaries of the field (e.g., hedgerows, grassy banks, fences, walls, ditches) which are known to vary according to soil characteristics and vegetation structure, the cropping system in the adjacent field and work organization at a farm level (De Snoo 1999; Le Cour et al. 2002). Crop management and boundary management both affect the distribution of weeds in the core and the margins of cultivated field as well as potential propagule exchanges between crops and the field margins. Here, we use the terminology field margin as defined by Marshall and Moonen (2002), i.e., the whole of the crop edge, any margin strip present (whether naturally occurring or set up for conservation or environmental purposes) and the semi-natural habitat associated with the boundary.
2.1 Effects of local management for weeds within the crop

Soil tillage and, to a lesser degree mechanical weeding, can disperse seeds over several meters parallel to the tractor movement (Rew and Cussans 1997; Grundy et al. 1999; Marshall and Brain 1999) and up to a meter in the perpendicular direction (Forcella and Lindstrom 1988; RogerEstrade et al. 2001). Harvesters also increase weed patch spread by several orders of magnitude, especially if harvest time coincides with seed set (Rew et al. 1996; Woolcock and Cousens 2000; Blanco-Moreno et al. 2004; Humston et al. 2005). There can substantial within-field spread of weeds from weed patches if weed density in the patch is intermediate or high (Wang et al. 2003; Boyd and White 2009; Humston et al. 2005). The spatial dynamics of annual weeds within the crop has been modeled with a neighborhood metapopulation level that considered the crop as a set of neighboring 1-m cells, allowing the within-crop spatiotemporal heterogeneity in habitat conditions within the crop to be variable (Perry and Gonzalez-Andujar 1993). Simulations show that dispersal between neighboring cells enhanced the persistence of the metapopulation in most conditions and that often modeled populations could persist in very small number for many generations, a pattern that bears resemblance with results derived from empirical longterm monitoring of blackgrass (Wilson and Brain 1991).

\subsection{Effects of local management for weeds within the field} margin

Field margins often shelter higher diversity and abundance of weed species than the core of cultivated fields (e.g., Marshall 1989; Romero et al. 2008; Kovacs-Hostyanszki et al. 2011). One likely explanation is the inability of many weed species to successfully establish within the crop because environmental constraints imposed by farming practices are too harsh, whereas these constraints are relaxed at the margin because crop management is less efficient (Wilson and Aebischer 1995; Kleijn and van der Voort 1997). However, herbicide application and drift in the crop edge often reduce the diversity of weed communities in margins (Kleijn and Snoeijing 1997; Aude et al. 2003). The practice of not spraying the crop edge significantly increases weed species diversity and abundance in the crop edges (De Snoo 1997) and in the adjacent field margin (De Snoo and van der Poll 1999). Fertilizers applied in the crop can concentrate in the crop edge and subsequent addition in nitrogen and phosphorous can alter weed communities (Rew et al. 1992; Tsiouris and Marshall 1998). Fried et al. (2009b) showed that many weed species that used to be frequent within the core of crops in the 1970s are now restricted to crop margins, as a result of a shift towards more intense crop management practices. In addition, field margins can be seen as uncultivated 
corridor-like habitats that could potentially enhance weed dispersal along well-connected networks of linear elements, although there is to our knowledge no evidence of such mechanism in weeds. A recent study (Van Geert et al. 2010) showed that linear landscape elements may act as functional biological corridors facilitating pollen dispersal through pollinator movements.

\subsection{Field boundary management and local weed dispersal}

Weed exchanges between the field and its boundary seem to occur in both directions (Marshall 1989) with some species located in the field that are able to exploit disturbed zones within the boundary and other species mainly occurring in the boundary and spreading into the field (Marshall 1989; Rew et al. 1996; West et al. 1997). Short distance seed dispersal from the margin to the field may explain why boundaries are often perceived by farmers as a source for crop infestation (Marshall and Smith 1987; Cordeau et al. 2011a) but also clearly contributes to enhanced weed diversity levels within generally impoverished cultivated fields (Roschewitz et al. 2005; Gabriel et al. 2006). Indeed, diversity within a field depends not only on the conditions within the crop, but also to connectivity at short distances between neighbouring habitats. Predicting weed species richness thus requires taking into account such neighborhood effects and therefore the spatial arrangement of the landscape elements (Wagner et al. 2000). Some authors also suggest that boundaries characterized by vertical and dense vegetation may be functioning as seed-trapping structures for anemochorous weeds (Bullock and Moy 2004; Poggio et al. 2010). In some cases, crops can be regarded as sink habitats fed by a constant propagule arrival from the nearby field margin "source" (vicinism sensu Zonneveld 1995). For example, in Argentina, most native perennial species occurring within fields could neither complete their life cycles nor produce a sufficient amount of propagules to sustain self-perpetuating populations in fields (Poggio et al. 2010). Also, because the propagation of weeds is clearly influenced by landscape arrangement at a very fine spatial scale, seed exchanges can be altered by the management of field margins, e.g., the establishment of wildflower mixes sown strips or grass strips between the boundary and the crop can significantly decrease weed ingress into the field (Smith et al. 1994; West et al. 1997; de Cauwer et al. 2008; Cordeau et al. 2011b). Such strips can also buffer boundaries from crop management practices such as herbicide drift (Marshall 2009).

\section{Dispersal constraints at the farm territory level}

Farm territorial management is the overall organization of farming activities on the farm territory, which accounts for production objectives, availability and organization of workforce, land and equipment resources (Aubry et al. 1998). Three types of activities are organized at the farm level, those related to production with implications in terms of land use allocation and crop/grassland management, those of land maintenance (e.g., field boundaries maintenance) and those of laying-out, which aims to install, remove, or significantly change the structure of some elements or groups of elements of the farm territory, such as field shape and patterns (Thenail et al. 2009). These three kinds of activities suppose a circulation of machinery between fields within the farm territory. All these activities, including circulation of machinery, potentially affect weed dispersal either directly or through changes in the availability of habitat and their spatial arrangement (size, isolation) at the farm level.

\subsection{Effects of land-use allocation at the farm level}

The choice of a cropping system at a field level is relative to the choices applied to the other fields within the farm territory. Crops are allocated to their fields by farmers according to rotational principles, within environmental (water supply, soil properties), socio-economic, and agronomic constraints (Rounsevell et al. 2003; Maxime et al. 1995; Papy 2001). On top of this, there are also adjustments of crop management practices at the farm level within the year in relation to the climatic conditions and due to constraints of work organization (Papy et al. 1988). The resulting land use allocation at the farm level usually clearly departs from randomness. Land use allocation often concerns several fields, e.g., when fields are small and/or far from the farmstead, a similar allocation minimizes costs because the different fields can be sown together, sprayed with pesticides together, fertilized and finally harvested together. Neighboring fields can also be allocated similarly because they share similar environmental constraints (Castellazzi et al. 2007; Thenail et al. 2009; Schaller et al. 2010). Conversely, the location of fields used for the multiplication of crop seeds will be constrained by minimum isolation distance in order to avoid contamination that would alter the quality of cultivars (Wang et al. 1997). The resulting spatial pattern of land-use types has impacts on weed populations at the farm level. For example, Colbach (2009) used a spatially explicit cropping system model to evaluate the impact of the spatial distribution of fields belonging to a single farm (clustered vs. scattered, see Fig. 5a) on the genetic harvest impurity of non-GM oilseed rape crops via a particular weed type, i.e., crop volunteers. Simulations show that clustered farms presented lower harvest impurity levels than farms composed of scattered fields, regardless of the cropping system type (intensive conventional vs. +organic) and the mean size of fields (Fig. 5b). 
Fig. 5 Simulation of the GENESYS model (Colbach, 2009). a Spatial pattern of fields at the farm level: scattered (left) and clustered (right). b Contamination rate in non-GM harvests according to the spatial pattern of fields (scattered vs. clustered) for five systems. The first letter of the system refers to the management ( $I$ intensive; $O$ organic) and the second letter refers to the size of individual fields ( $S$ 1-2 ha; $M$ 5-6 ha; $L$ 13 ha). $I M$ intensive medium field size; $O M$ organic medium field size; $O S$ organic small field size; $I L$ intensive large field size; $O L$ organic large field size a

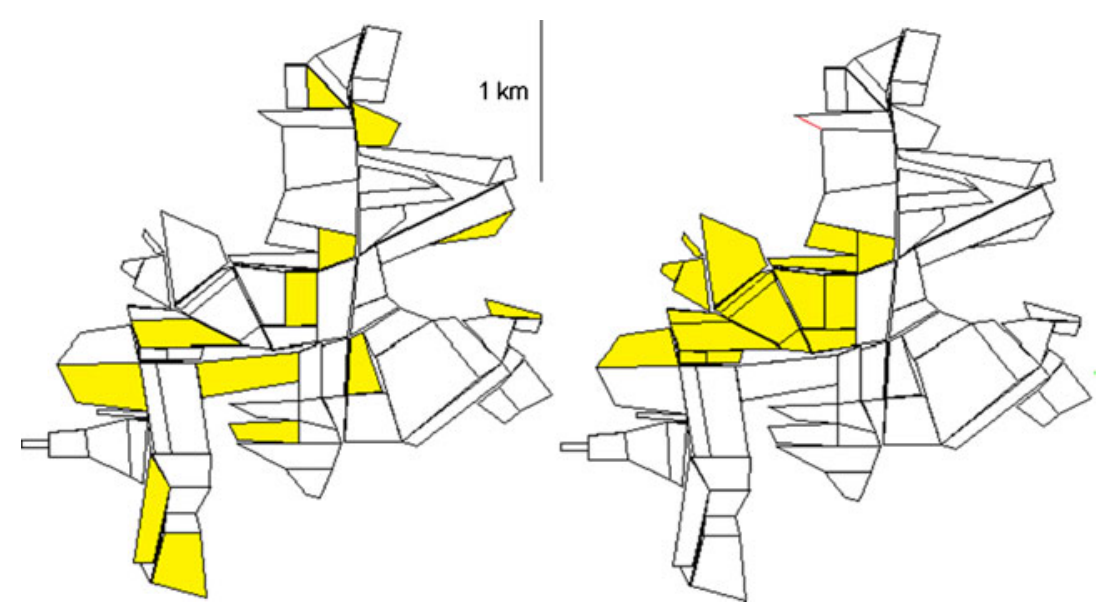

b

\subsection{Effects of agricultural circulation within the farm}

Agricultural circulation is a key issue in farm territorial management and includes all the movements in farms with machinery or animals, by the mean of vehicles or by foot, for, e.g., the transport of product or material, the move of dairy cows to milking place, the implementation of crop management practices, or the survey of crop growth or animals in pasture (Gibon et al. 1988; Morlon and Trouche 2005a, b). These movements result in the transportation of weed seeds by the machines from one field to another within the farm territory. Harvesters have been shown to carry significant weed seed loads (on average 30,000 seeds per harvester) when harvest coincides with weed seed maturation (Boyd and White 2009). The transport of harvests from one field to another and from fields towards the silo also affects the distribution of weeds at the farm level (Pessel and Lecomte 2000). Weed seed can also move between paddocks with machinery (McCanny and Cavers 1988) or be transported after ingestion by cattle and shed directly in pastures or spread via manure in arable fields (Pleasant and Schlather 1994). Seeds of many weed species can also get hooked on cow or sheep coat, according to their mass and morphology (Römermann et al. 2005).

\subsection{Effects of laying-out the farm territory}

Altering the size and shape of fields or the distribution of semi-natural elements within the farm territory can affect weed distribution. Farmers implement such structural changes in order to adapt the structure of their farm territory to their objectives, after land consolidation programs or independently (Fig. 6). In terms of impacts on weeds, field enlargement reduces the density of field edges, a habitat usually rich in weed species. Simulations testing the effect of field size on the level of harvest impurity in non-GM oilseed rape crops mainly due to crop volunteers showed that farms with small fields presented a significantly higher harvest impurity levels than farms with large fields (Colbach et al. 2009). Few studies have however assessed the impact of structural changes on a possible shift in weed communities, and to our knowledge, none at the farm level.

\section{Dispersal constraints at the landscape scale}

Landscape patterns result from the diversity of farm territorial management at field and farm level and the fine interweaving of farm territories as well as the amount and spatial 
Fig. 6 Examples of joint dynamics of field laying-out and crop rotations (aerial photos, ZA Pleine-Fougères): (i) «bocage» islet with removed hedgerows, changes in field patterns and land-use conversion, (ii) «openfield» islet with year to year adaptation of field patterns according to crop rotation and required surface
1998

i)
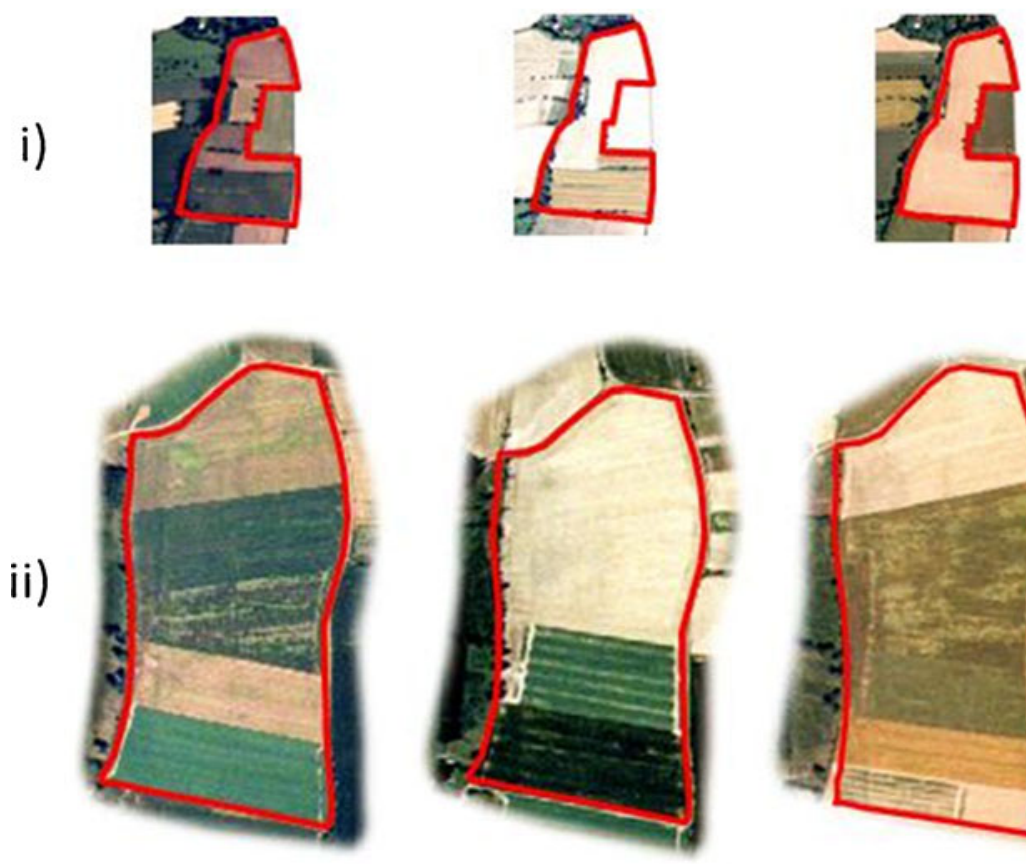

1999

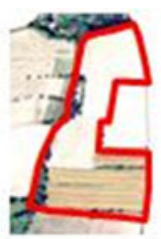

2000

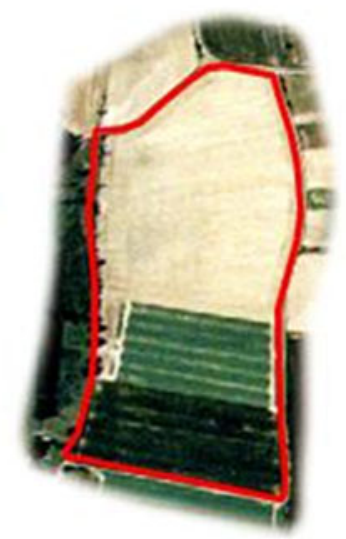

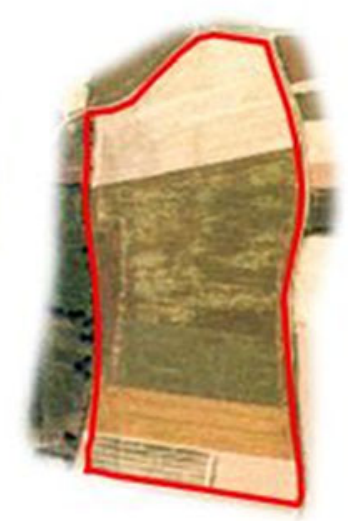

patterns of non cultivated land. The structuring of farm territories at the landscape scale results from two combined processes. Segmentation occurs when geographical areas differentiated by their physical environment, climate, but also social-economical development contribute to a "selection" of types of farming systems and associated land use (Thenail 2002; Mignolet et al. 2007). The complementary process is an aggregation of individual farms and farming activities leading to mosaics of different levels and types of heterogeneity. In the UK for example, organic farms have been shown to be inherently aggregated in areas environmentally less favorable for arable agriculture (Gabriel et al. 2009) and as such located in more diverse and complex landscapes than conventional farms (Norton et al. 2009). In addition, landscape patterns can be impacted by collective concerted actions, i.e., situations where multiple land managers within a landscape coordinate their crop management actions. This has been studied in the case of farmers sharing the same machinery to harvest crops, and/or when harvesting of nearby fields belonging to different farmers is done by the same company of agricultural services. In these cases, in order to facilitate the harvest, crop location on fields can be coordinated between several farmers (Morlon and Trouche 2005b; Capitaine 2005). Another type of coordination of cropping system beyond the farm level exists between farmers and cooperatives in order to achieve for a same crop, a same targeted quality at the cooperative level (Le Bail et al. 2006). Finally, concerted actions for crop spatial arrangement and weed management could be an important lever for controlling herbicide resistance in noxious weeds at the landscape level (Dauer et al. 2009). This diversity of processes creates an important heterogeneity in the spatial distribution of factors affecting weed dispersal across the landscape.

\subsection{Effects of landscape spatial patterns on weed communities}

A number of studies have compared the weed flora among fields located in landscapes strongly differing in terms of land use composition, e.g., proportion of semi-natural habitats, grassland, and arable land and structure, e.g., mean field size (see Table 1). Overall, this corpus of studies provides evidence that weed diversity measured both at the field and at landscape level is driven by landscape characteristics (Table 1, RWL) and local practices at the field level (Table 1, RWF), and that these effects are independent one from another at least for part of the studies (Table 1, independence FL). Weed diversity is in general higher in "complex landscapes" than in simple ones, as often been shown in other taxa (Heikkinen et al. 2004; Rundolf and Smith 2006). A common explanation is that complex landscapes harbor more diverse habitats and therefore more ecological niches, hence a larger regional species pool (Tews et al. 2004; Tamme et al. 2010). For weeds, this view is supported by the fact that beta diversity is higher in complex landscapes than in simple ones, i.e., that weed communities in different fields located within a complex landscape differ more strongly one from another than weed communities 
Table 1 Summary results of studies that have tested the effect of landscape variables on weed diversity

\begin{tabular}{|c|c|c|c|c|}
\hline $\begin{array}{l}\text { Landscape } \\
\text { variable }\end{array}$ & $\begin{array}{l}\text { RWL relation weed/ } \\
\text { landscape }\end{array}$ & $\begin{array}{l}\text { RWF relation weed/field } \\
\text { management }\end{array}$ & $\begin{array}{l}\text { FL field management and landscape } \\
\text { variables independent? }\end{array}$ & Reference and country \\
\hline \multirow[t]{4}{*}{ Mean field size } & ns & $\mathrm{N} / \mathrm{A}$ & & $\begin{array}{l}\text { Baessler and Klotz 2006; } \\
\text { Germany }\end{array}$ \\
\hline & $(-)$ & $\mathrm{N} / \mathrm{A}$ & & Gaba et al. 2010; France \\
\hline & ns & $\operatorname{AES}(+)$ & Yes & Marshall 2009; UK \\
\hline & ns & OF $(+)$ & No & Hawes et al. 2010; UK \\
\hline \multirow{7}{*}{$\begin{array}{l}\text { Percentage of } \\
\text { arable land }\end{array}$} & $(-)$ & Nitrogen $(-)$ & Yes & Gabriel et al. 2005; Germany \\
\hline & $(-)$ & Nitrogen $(-)$ & Yes & Gabriel et al. 2006; Germany \\
\hline & ns & $\mathrm{OF}(+)$ & Yes & $\begin{array}{l}\text { Holzschuh et al. 2007; } \\
\text { Germany }\end{array}$ \\
\hline & $(-)$ & $\mathrm{OF}(+)$ & Yes & $\begin{array}{l}\text { Roschewitz et al. 2005; } \\
\text { Germany }\end{array}$ \\
\hline & ns & Nitrogen $(-)$ & Yes & José-Maria et al. 2010 ; Spain \\
\hline & $(-)$ & $\mathrm{N} / \mathrm{A}$ & & $\begin{array}{l}\text { De la fuente et al. } 2010 ; \\
\text { Argentina }\end{array}$ \\
\hline & $(-)$ & Nitrogen $(-)$ & No & $\begin{array}{l}\text { Kovacs-Hostyanszki et al. } \\
\text { 2011; Hungary }\end{array}$ \\
\hline \multirow[t]{6}{*}{ Edge density } & $(+)$ & Nitrogen $(-)$ & Yes & Gabriel et al. 2005; Germany \\
\hline & $(+)$ & Herbicide $(-)$ & Not checked & Guerrero et al. 2010; Spain \\
\hline & $(+)$ & $\operatorname{AES}(+)$ & Yes & Concepcion et al. 2008; Spain \\
\hline & $(+)^{\mathrm{a}}$ & ns & No & Weibull et al. 2003; Sweden \\
\hline & ns & $\mathrm{N} / \mathrm{A}$ & & $\begin{array}{l}\text { Baessler and Klotz 2006; } \\
\text { Germany }\end{array}$ \\
\hline & $(+)$ & $\mathrm{N} / \mathrm{A}$ & & Poggio et al. 2010; Argentina \\
\hline \multirow[t]{7}{*}{ Habitat diversity } & ns & $\mathrm{N} / \mathrm{A}$ & & Gaba et al. 2010; France \\
\hline & ns & Herbicide $(-)$ & Not checked & Guerrero et al. 2010; Spain \\
\hline & ns & $\operatorname{AES}(+)$ & Yes & Concepcion et al. 2008; Spain \\
\hline & ns & $\mathrm{OF}(+)$ & No & Ekroos et al. 2010; Finland \\
\hline & ns & ns & No & Weibull et al. 2003; Sweden \\
\hline & ns & $\mathrm{OF}(+)$ & No & Boutin et al. 2008; Canada \\
\hline & $(+)$ & Nitrogen $(-)$ & Yes & Gabriel et al. 2005; Germany \\
\hline
\end{tabular}

RWL correlation between weed diversity and landscape variable; RWF correlation between weed diversity and field management $(A E S=$ agrienvironmental scheme; $O F=$ organic farming system; herbicide=number of herbicide applications; nitrogen=amount of nitrogen fertilization); N/ A, non-applicable as no field management data was available in the survey; ns $p>0.05 ;(-)$ significant negative correlation; $(+)$ significant positive relationship; independence indicates when there is a significant correlation between the field management variable and the landscape variable tested in each study (yes, no, not checked)

${ }^{a}$ Denotes that the relationship was only true in conventional farming systems

recorded in different fields within a simpler landscape, which are more similar to each other (Roschewitz et al. 2005; Gabriel et al. 2006; Poggio et al. 2010). Complex landscapes also often shelter more natural and semi-natural habitats which can increase the landscape weed species pool (Le Cœur et al. 1997). Landscape composition can indeed impact weed diversity, for example, the proportion of landscape occupied by annuals crops is often inversely correlated to weed richness (Table 1). Yet, other landscape metrics, such as landscape diversity failed to explain weed biodiversity in any significant way (Table 1) which might suggest that land use types used to quantify landscape diversity are maybe not well matched with what constitutes habitat or niche diversity for weeds. Metrics describing landscape structure (grain) such as the size of fields or the edge density in a given landscape also appear to impact weed diversity, smaller-grain landscapes sheltering more weed species. This result is quite intuitive as the dispersal of propagules from field boundaries to the core field leads to increased weed diversity in the field (see "Introduction" section) and therefore the denser the network of field boundaries (i.e., edge density), the higher the probability that many species randomly immigrate in the field (spatial mass effect or vicinity). This is true for field margins but could also well apply 
for any alternative weed habitat neighboring the field (setaside, fallow crop, ...). This view is supported by analyses showing that individual core fields located in a complex landscape are not only more dissimilar to each other in terms of weed communities, but each field also harbors more weed species (Roschewitz et al. 2005; Boutin et al. 2008; Poggio et al. 2010).

\subsection{Evidence for long distance dispersal in weeds}

The recurrent success of alien weed species (Chauvel et al. 2006) and the important turnover observed in weed communities over decades, with a substantial number of "new" species (Fried et al. 2009b) are indirect evidence that weed dispersal does occur over large spatial and temporal scales. Quantitative estimates of seed dispersal at the landscape level remain scarce and obtaining these by direct measure remains problematic (Nathan 2006). Seed immigration from neighbouring fields has been shown to explain $30 \%$ of feral oilseed rape populations occurring at the landscape level (Pivard et al. 2008). There is also empirical evidence for long distance seed dispersal along road networks with vehicle traffic (von der Lippe and Kowarik 2007; Garnier et al. 2008), trucks transporting contaminated crop seeds (Donald and Ogg 1991), or through the circulation of machinery used for roadside verges management (Vitalos and Karrer 2009).

\subsection{Functional approaches for weed dispersal constraints over large scales}

Within communities, the response of individual species and the scale at which it occurs has been shown to be mediated by a number of species life-history attributes, such as the species dispersal ability (Butaye et al. 2001; Fahrig 2001) or its degree of habitat specialization (Devictor et al. 2008; Liira et al. 2008). As a result, communities are assemblages of species with different spatial strategies (Tscharntke and Brandl 2004). In the case of weeds, one can thus hypothesize that not all species will respond to landscape patterns in the same way, according to their life-traits such as their degree of habitat specialization (Fried et al. 2010), as the dispersal type (dispersal over space), the level of seed persistence and dormancy (dispersal over time), the reproduction mode. The relevance of trait-based approach in landscape scale weed research can be illustrated with a case study summarized in Table 2 . We conducted a weed survey in two adjacent landscapes in Brittany (part of the LTER site of Pleine-Fougères/Armorique http://osur.univ-rennes1.fr/ zoneatelier-armorique/), a traditional hedgerow network landscape ("bocage") and a landscape that was originally similar to the first one but which went through a reallotment program in the early 1990s. The shift in winter-wheat weed communities following the reallotment led to an important decline in weed diversity at the field level but also at the landscape level. The interesting point is that this loss of weed species was not random. The realloted landscape harbored significantly less entomogamous plants and more anemogamous plants than the adjacent hedgerow network landscape. As landscape structure (habitat density, connectivity) affects on-farm biodiversity, including pollinators (Holzschuh et al. 2009, 2010); it would be interesting to assess whether the loss of entomogamous weed species in the realloted landscape could be linked to a parallel decline of insects or a change in the interactions between weeds and pollinators (Tscharntke and Brandl 2004; Gonzalez et al. 2011).

\section{Discussion}

\subsection{Weed dispersal at multiple scales}

From this review, we can conclude that weed dispersal is impacted by agricultural management at the three spatial scales we have addressed here. Substantial evidence was gathered that suggest a role of large scale factors in the assemblage of weeds within cultivated fields. Our analysis suggests that from a weed's perspective, agricultural landscapes are non-random spatio-temporal arrangements of more or less suitable patches of habitat (fields, margins) which organization is strongly shaped by farmers' decisions at different spatial scales (Fig. 7). First of all, the overall species pool is partly determined by landscape characteristics such as the heterogeneity of habitat types. Second, long distance weed dispersal events, whether they occur naturally or through anthropogenic activities do occur and are regulated by the landscape spatial pattern, i.e., clustering of crop types, density of network of transportation, density and connectivity of networks of field margins. These long distance events suggest a metapopulation structuring of weeds at the landscape level. Third, because neighboring effects between the core of fields and their margins have a strong effect on what species are actually present within the crop and because weed assemblages occurring in field margins are affected by landscape characteristics (density, connectivity), short distance dispersal and its associated local scale population functioning (spatial mass effect) does actually translate the effect of large-scale factors into the crop itself.

\subsection{Implications for weed management}

This analysis shows that in the case of weed management, we are confronted with a spatial scale mismatch between ecological processes (here, weed dispersal across the field and the landscape) and management processes developing at the field and farm level (Cumming et al. 2006). The farm 
Table 2 Comparison of landscape attributes, weed diversity, Bray Curtis similarity indices between fields within a landscape type and the proportion of individual plants divided into the three main reproduction types for two adjacent landscapes (realloted and not realloted)
$T$ test $n=15$ winter wheat fields within each landscape type

\begin{tabular}{lllr}
\hline & Landscape non-realloted & Landscape realloted & $t$ \\
\hline Landscape attributes at $300 \mathrm{~m}$ & & & \\
Hedgerow density & $93.86 \pm 6.01$ & $42.29 \pm 2.64$ & $7.85^{* *}$ \\
Percentage of arable crop & $11.99 \pm 2.51$ & $44.60 \pm 2.79$ & $-8.70^{* *}$ \\
Percentage of permanent grassland & $36.63 \pm 3.16$ & $13.00 \pm 2.38$ & $5.97^{* *}$ \\
Weed diversity & & & $3.86^{* *}$ \\
Field ( $\alpha$ diversity) & $2.10 \pm 0.13$ & $1.15 \pm 0.21$ & - \\
Landscape $(\gamma$ diversity) & 3.73 & 2.65 & - \\
Similarity Bray-Curtis & $0.26 \pm 0.01$ & $0.39 \pm 0.03$ & $-3.95^{* *}$ \\
Weed reproduction mode & & $63.51 \pm 8.03$ & 1.06 \\
Percent anemogamy & $25.32 \pm 5.37$ & $17.24 \pm 6.92$ & $3.43^{* *}$ \\
Percent autogamy & $26.90 \pm 5.40$ & $19.25 \pm 5.94$ & \\
Percent entomogamy & $47.78 \pm 5.56$ & & \\
\hline
\end{tabular}

territory is a key management unit but weed population processes do not recognize boundaries between farms. Similar interactions have been shown for agri-environmental schemes that are implemented at the field/farm level but are expected to provide biodiversity benefits at the landscape level (Aviron et al. 2009). Resolving such mismatches requires a better articulation between the representation of ecological and managerial processes using available theoretical frameworks such as hierarchichal theory and socialecological systems (Pelosi et al. 2010). Building on the previous point, it appears logical to assess the conditions for efficient collective concerted actions on weed management, together with the effects of non-concerted spatial aggregation of management activities. There are indeed too few documented examples where multiple land managers within a landscape coordinate their crop and weed management actions. However, some examples of collective management between farmers have been studied in the case of farmers sharing the same machinery to harvest crops, and/or when harvesting of nearby fields belonging to different farmers is
Total species pool

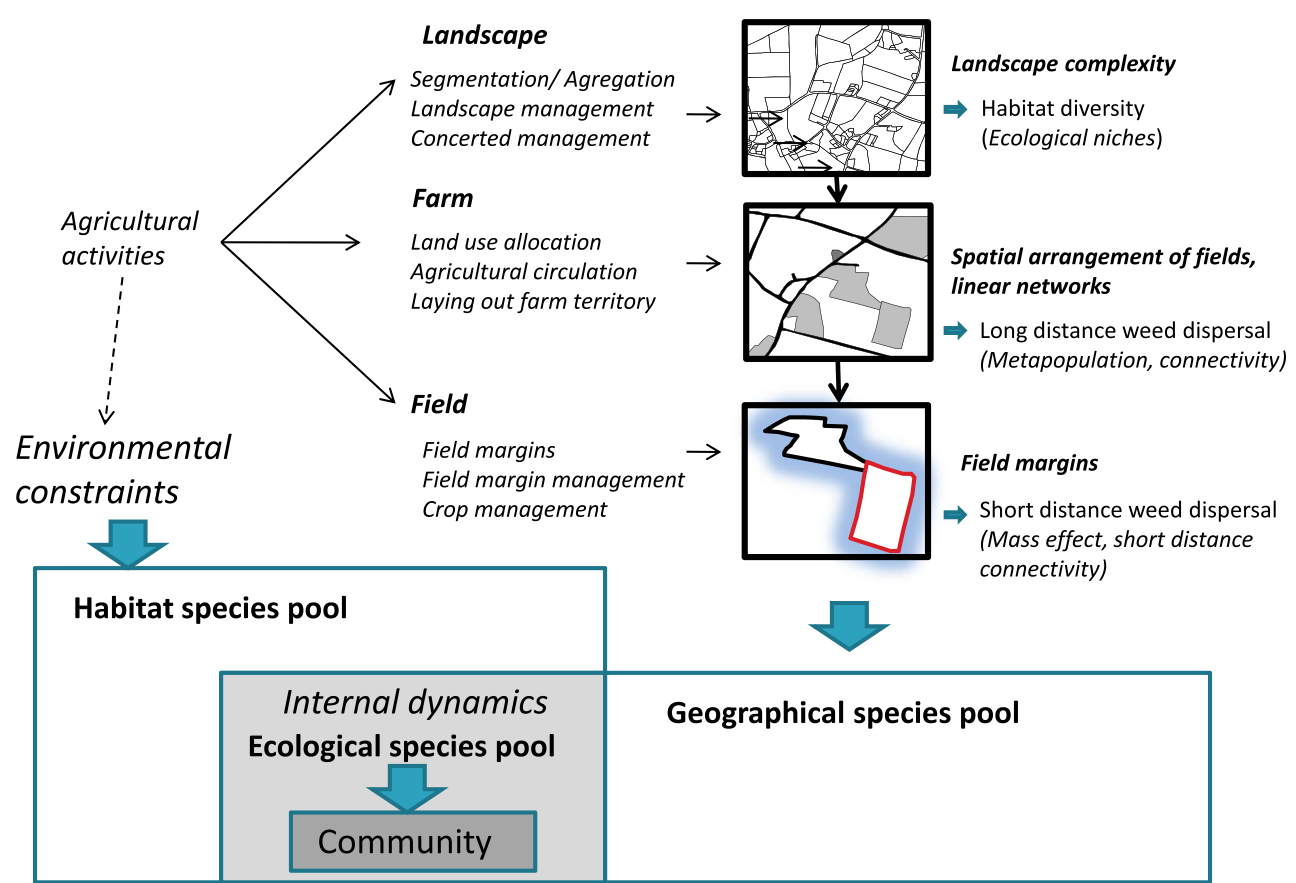

Fig. 7 The functional trait-based community assembly conceptual framework, modified from Booth and Swanton (2002). The geographical pool of species is determined by dispersal constraints that are affected by agricultural activities carried out at the field, farm, and landscape levels. These activities affect the diversity and spatiotemporal arrangement of weed habitats at various ecological spatial scales and have thus implications on the number of ecological niches available as well as on connectivity at short and large distances 
done by the same company of agricultural services. In these cases, in order to facilitate the harvest, crop allocation in fields can be coordinated between several farmers (Morlon and Trouche 2005b; Capitaine 2005). Another type of coordination of cropping system beyond the farm level exists between farmers and cooperatives in order to achieve for a same crop a same targeted quality at the cooperative level (Le Bail et al. 2006). Based on such experiences, it should be possible to use scenario modeling to explore how alternative configurations of collective organizations between farmers and other land users may affect the distribution of weed diversity and of problematic weeds over the landscape.

Acknowledgements This review was funded by ANR STRA-08-02 "Agroecological management of arable weeds". We wish to thank the anonymous reviewers who provided very useful suggestions on an earlier draft of the manuscript. Thanks to Xavier Reboud, Guillaume Fried and Claire Lavigne for their support and comments.

\section{References}

Andreasen C, Stryhn H, Streibig JC (1996) Decline of flora in Danish arable fields. J Appl Ecol 33:619-626. doi:10.2307/2404990

Aubry C, Papy F, Capillon A (1998) Modelling of decision-making processes for annual crop management. Agric Syst 56:45-65. doi:10.1016/S0308-521X(97)00034-6

Aude E, Tybirk K, Pedersen MB (2003) Vegetation diversity of conventional and organic hedgerows. Agric Ecosyst Environ 99:135147. doi:10.1016/S0167-8809(03)00146-4

Aviron S, Nitsch H, Jeanneret P, Buholzer S, Luka H, Pfiffner L, Pozzi S, Schüpbach B, Walter T, Herzog F (2009) Ecological cross compliance promotes farmland biodiversity in Switzerland. Front Ecol Environ 7:247-252. doi:10.1890/070197

Baessler C, Klotz S (2006) Effects of changes in agricultural land-use on landscape structure and arable weed vegetation over the last 50 years. Agric Ecosyst Environ 115:43-50. doi:10.1016/ j.agee.2005.12.007

Bastiaans L, Kropffa MJ, Goudriaanb J, van Laar HH (2000) Design of weed management systems with a reduced reliance on herbicides poses new challenges and prerequisites for modeling crop-weed interactions. Field Crop Res 67:161-179. doi:10.1016/S03784290(00)00091-5

Bohan DA, Hawes C, Haughton AJ, Denholm I, Champion GT, Perry JN, Clark SJ (2007) Statistical models to evaluate invertebrateplant trophic interactions in arable systems. Bull Entomol Res 97:265-280. doi:10.1017/S0007485307004890

Bohan DA, Powers SJ, Champion G et al (2011) Modelling rotations: can crop sequences explain arable weed seedbank abundance. Weed Res 51:422-432. doi:10.1111/j.1365-3180.2011.00860.x

Booth BD, Swanton CJ (2002) Assembly theory applied to weed communities. Weed Sci 50:2-13

Boutin C, Baril A, Martin PA (2008) Plant diversity in crop fields and woody hedgerows of organic and conventional farms in contrasting landscapes. Agric Ecosyst Environ 123:185-193. doi:10.1016/ j.agee.2007.05.010

Blanco-Moreno JM, Chamorro L, Massales RM, Recasens J, Sans FX (2004) Spatial distribution of Lolium rigidum seedlings following seed dispersal by combine harvesters. Weed Res 44:375-387
Boyd NS, White S (2009) Impact of wild blueberry harvesters on weed seed dispersal within and between fields. Weed Sci 57:541-546. doi:10.1614/WS-08-156.1

Bullock JM, Moy IL (2004) Plants as seed traps: inter-specific interference with dispersal. Acta Oecol 25:35-41. doi:10.1016/ j.actao.2003.10.005

Butaye J, Jacquemyn H, Hermy M (2001) Differential colonization causing non-random forest plant community structure in a fragmented agricultural landscape. Ecography 24:369-380. doi:10.1034/j.16000587.2001.d01-193.x

Capitaine M (2005) Organisation des territoires des exploitations agricoles. Impact du recours à des collectifs d'action : la conduite de chantiers de récolte en CUMA. PhD thesis, INPL, France

Cardina J, Herms CP, Doohan DJ (2002) Crop rotation and tillage system effects on weed seedbanks. Weed Science 50:448-460

Castellazzi MS, Perry JN, Colbach N, Monod H, Adamczyk K, Viaud V, Conrad K (2007) New measures and tests of temporal and spatial pattern of crops in agricultural landscapes. Agric Ecosyst Environ 118:339-349. doi:10.1016/j.agee.2006.06.003

Chauvel B, Dessaint F, Cardinal-Legrand C, Bretagnolle F (2006) The historical spread of Ambrosia artemisiifolia L. in France from herbarium records. J Biogeog 33:665-673. doi:10.1111/j.13652699.2005.01401.x

Concepcion ED, Diaz M, Baquero RA (2008) Effects of landscape complexity on the ecological effectiveness of agri-environmental schemes. Landsc Ecol 23:135-148. doi:10.1007/s10980-0079150-2

Colbach N (2009) How to model and simulate the effects of cropping systems on population dynamics and gene flow at the landscape level. Example of oilseed rape volunteers and their role for coexistence of GM and non-GM crops. Environ Sci Pollut Res 16:348-360. doi:10.1007/s11356-008-0080-6

Colbach N, Monod H, Lavigne C (2009) A simulation study of the effects of field patterns on cross-pollination rates in oilseed rape. Ecol Model 220:662-672. doi:10.1016/j.ecolmodel.2008.11.020

Cordeau S, Reboud X, Chauvel B (2011a) Farmers' fears and agroeconomic evaluation of sown grass strips in France. Agron Sustain Dev 31:463-473. doi:10.1007/s13593-011-0004-6

Cordeau S, Petit S, Reboud X, Chauvel B (2011b) Sown grass strips harbour high weed diversity but decrease weed richness in adjacent crops. Weed Res 52:88-97. doi:10.1111/j.13653180.2011.00892.x

Cumming GS, Cumming DHM, Redman CL (2006) Scale mismatches in social- ecological systems: causes, consequences, and solutions. Ecol Soc 11:Art. 14

Dauer JT, Luschei EC, Mortensen DA (2009) Effects of landscape composition on spread of an herbicide-resistant weed. Landsc Ecol 24:735-747. doi:10.1007/s10980-009-9345-9

De Cauwer B, Rehaul D, Nijs I, Milbau A (2008) Management of newly established field margins on nutrient-rich soil to reduce weed spread and seed rain into adjacent crops. Weed Res 48:102112. doi:10.1111/j.1365-3180.2007.00607.x

De la Fuente EB, Perelman S, Ghersa FM (2010) Weed and arthropod communities in soyabean as related to crop productivity and land use in the Rolling Pampa, Argentina. Weed Res 50:561-571. doi:10.1111/j.1365-3180.2010.00811.x

Délye C, Clément J, Pernin F, Chauvel C, Le Corre V (2010) High gene flow promotes the genetic homogeneity of arable weed populations at the landscape level. Basic Appl Ecol 11:504-512. doi:10.1016/j.baae.2010.06.008

De Snoo GR (1997) Arable flora in sprayed and unsprayed crop edges. Agric Ecosyst Environ 66:223-231. doi:10.1016/S0167-8809(97) 00104-7

De Snoo GR (1999) Unsprayed field margins: effects on environment, biodiversity and agricultural practice. Lands Urban Plan 46:151160. doi:10.1016/S0169-2046(99)00039-0 
De Snoo GR, van der Poll RJ (1999) Effect of herbicide drift on adjacent boundary vegetation. Agric Ecosyst Environ 73:1-6. doi:10.1016/ S0167-8809(99)00008-0

Devictor V, Julliard R, Jiguet F (2008) Distribution of specialist and generalist species along spatial gradients of habitat disturbance and fragmentation. Oikos 117:507-514. doi:10.1111/j.2008.00301299.16215.x

Dieleman JA, Mortensen DA (1999) Characterizing the spatial pattern of Abutilon theophrasti seedling patches. Weed Res 39:455-467

Donald WW, Ogg AG (1991) Biology and control of jointed goatgrass (Aegilops cylindrical), a review. Weed Technol 5:3-17

Ehrlén J, Eriksson O (2003) Large-scale spatial dynamics of plants: a response to Freckleton \& Watkinson. J Ecol 91:316-320. doi:10.1046/j.1365-2745.2003.00753.x

Ekroos J, Hyvonen T, Tiainen J, Tiira M (2010) Responses in plant and carabid communities to farming practices in boreal landscapes. Agric Ecosyst Environ 135:288-293. doi:10.1016/j.agee.2009.10.007

Fahrig L (2001) How much habitat is enough? Biol Conserv 100:6574. doi:10.1016/S0006-3207(00)00208-1

Firbank LG, Petit S, Smart SM, Blain A, Fuller RJ (2008) Assessing the impacts of agricultural intensification on biodiversity: a British perspective. Philos Trans R Soc London [Biol] 363:777-787. doi:10.1098/rstb.2007.2183

Forcella F, Lindstrom MJ (1988) Movement and germination of weed seeds in ridge-till crop production systems. Weed Sci 36:56-59

Freckleton RP, Watkinson AR (2002) Large-scale spatial dynamics of plants: metapopulations, regional ensembles and patchy populations. J. Ecol. 90, 419-434.

Fried G, Norton LR, Reboud X (2008) Environmental and management factors determining weed species composition and diversity in France. Agric Ecosyst Environ 128:68-76. doi:10.1016/ j.agee.2008.05.003

Fried G, Chauvel B, Reboud X (2009a) A functional analysis of largescale temporal shifts from 1970 to 2000 in weed assemblages of sunflower crops in France. J Veg Sci 20:49-58. doi:10.1111/ j.1654-1103.2009.05284.x

Fried G, Petit S, Dessaint F, Reboud X (2009b) Arable weed decline in Northern France: crop edges as refugia for weed conservation? Biol Conserv 142:238-243. doi:10.1016/ j.biocon.2008.09.029

Fried G, Petit S, Reboud X (2010) A specialist-generalist classification of the French arable flora and its response to changes in agricultural practices. BMC Ecol 10:20. doi:10.1186/1472-6785-10-20

Gaba S, Chauvel B, Dessaint F, Bretagnolle V, Petit S (2010) Weed species richness in winter wheat increases with landscape heterogeneity. Agric Ecosyst Environ 138:318-323. doi:10.1016/j.agee. 2010.06.005

Gabriel D, Thies C, Tscharntke T (2005) Local diversity of arable weeds increases with landscape complexity. Perspect Plant Ecol Evol Syst 7:85-93. doi:10.1016/j.ppees.2005.04.001

Gabriel D, Roschewitz I, Tscharntke T, Thies C (2006) Beta diversity at different spatial scales: plant communities in organic and conventional agriculture. Ecol Appl 16:2011-2021. doi:10.1890/ 1051-0761(2006)016[2011:BDADSS]2.0.CO;2

Gabriel D, Carver SJ, Durham H, Kunin WE, Palmer RC, Salt SM, Stagl S, Benton TG (2009) The spatial aggregation of organic farming in England and its underlying environmental correlates. J Appl Ecol 46:323-333. doi:10.1111/j.1365-2664.2009.01624.x

Gabriel D, Salt SM, Hodgson JA, Schmutz U, Kunin WE, Benton TG (2010) Scale matters: the impact of organic farming on biodiversity at different spatial scales. Ecol Lett 13:858-869. doi:10.1111/ j.1461-0248.2010.01481.x

Garnier A, Pivard S, Lecomte J (2008) Measuring and modelling antropogenic secondary seed dispersal along roadverges for feral oil seed rape. Basic Appl Ecol 9:533-541. doi:10.1016/ j.baae.2007.08.014
Gibbons DW, Bohan DA, Rothery P et al (2006) Weed seed resources for birds in fields with contrasting conventional and genetically modified herbicide-tolerant crops. Proc R Soc B. doi:10.1098/ rspb.2006.3522

Gibon A, Roux M, Vallerand F (1988) Eleveur, troupeau et espace fourrager. Contribution à l'approche globale des systèmes d'élevage. INRA SAD, Paris

Gonzalez A, Rayfield B, Lindo Z (2011) The disentangled bank: how loss of habitat fragments and disassembles ecological networks. Am J Bot 98:503-516. doi:10.3732/ajb.1000424

Grundy AC, Mead A, Burston S (1999) Modelling the effect of cultivation on seed movement with application to the prediction of weed seedling emergence. J Appl Ecol 36:663-678. doi:10.1046/ j.1365-2664.1999.00438.x

Guerrero I, Martínez P, Morales MB, Onate JJ (2010) Influence of agricultural factors on weed, carabid and bird richness in a Mediterranean cereal cropping system. Agric Ecosyst Environ 138:103108. doi:10.1016/j.agee.2010.04.006

Gunton RM, Petit S, Gaba S (2011) Functional traits relating arable weed communities to crop characteristics. J Veg Sci 22:541-550. doi:10.1111/j.1654-1103.2011.01273.x

Hallgren E, Palmer MW, Milberg P (1999) Data diving with cross validation: an investigation of broad-scale gradient in Swedish weed communities. J Ecol 87:1037-1051. doi:10.1046/j.13652745.1999.00413.x

Hawes C, Squire GR, Hallett PD, Watson CA, Young M (2010) Arable plant communities as indicator of farming practice. Agric Ecosyst Environ 138:17-26. doi:10.1016/j.agee.2010.03.010

Heikkinen RK, Luoto M, Virkkala R, Rainio K (2004) Effects of habitat cover, landscape structure and spatial variables on the abundance of birds in an agricultural-forest mosaic. J Appl Ecol 41:824-835. doi:10.1111/j.0021-8901.2004.00938.x

Holzschuh A, Steffan-Dewenter I, Kleijn D, Tscharnke T (2007) Diversity of flower-visiting bees in cereal fields: effects of farming system, landscape composition and regional context. J Appl Ecol 44:41-49. doi:10.1111/j.1365-2664.2006.01259.x

Holzschuh A, Steffan-Dewenter I, Tscharntke T (2009) Grass strip corridors in agricultural landscapes enhance nest-site colonization by solitary wasps. Ecol Appl 19:123-132. doi:10.1890/08-0384.1

Holzschuh A, Steffan-Dewenter I, Tscharntke T (2010) How do landscape composition and configuration, organic farming and fallowstrips affect the diversity of bees, wasps and their parasitoids? J Anim Ecol 79:491-500. doi:10.1111/j.1365-2656. 2009.01642.x

Humston R, Mortensen DA, Bjornstad ON (2005) Anthropogenic forcing on the spatial dynamics of an agricultural weed: the case of the common sunflower. J Appl Ecol 42:863-872. doi:10.1111/ j.1365-2664.2005.01066.x

Hyvonen T, Huusela-Veistola E (2008) Arable weeds as indicators of agricultural intensity. A case study from Finland. Biol Cons 141:2857-2864. doi:10.1016/j.biocon.2008.08.022

José-Maria L, Armengot L, Blanco-Moreno JM, Montserrat B, Sans FX (2010) Effects of agricultural intensification on plant diversity in Mediterranean dryland cereal fields. J Appl Ecol 47:832-840. doi:10.1111/j.1365-2664.2010.01822.x

Kleijn D, Snoeijing GIJ (1997) Field boundary vegetation and the effects of agrochemical drift: botanical change caused by low levels of herbicide and fertilizer. J Appl Ecol 34:1413-1425. doi:10.2307/ 2405258

Kleijn D, van der Voort LAC (1997) Conservation headlands for rare arable weeds: the effects of fertilizer application and light penetration on plant growth. Biol Conserv 81:57-67. doi:10.1016/ S0006-3207(96)00153-X

Kovacs-Hostyanszki A, Batary P, Baldi A, Harnos A (2011) Interaction of local and landscape features in the conservation of Hungarian arable 
weed diversity. Appl Veg Sci 14:40-48. doi:10.1111/j.1654109X.2010.01098.x

Le Bail M, Aubry C, Navarrete M, Vaucelle A (2006) Agronomie et qualité dans les filières de production végétale. In: Doré $\mathrm{T}$, Le Bail M, Martin P, Ney B, Roger-Estrade J (eds) L'agronomie aujourd'hui. Editions Quae, France, pp 225-310

Le Bail M, Lecroart B, Gauffreteau A, Angevin F, Messean A (2010) Effect of the structural variables of landscapes on the risks of spatial dissemination between GM and non-GM maize. Eur J Agron 33:12-23. doi:10.1016/j.eja.2010.02.002

Le Cœur D, Baudry J, Burel F (1997) Field margins plant assemblages: variation partitioning between local and landscape factors. Landsc Urban Plann 37:57-71. doi:10.1016/S0169-2046(96)00370-2

Le Cœur D, Baudry J, Burel F, Thenail C (2002) Why and how we should study field boundaries biodiversity in an agrarian landscape context. Agric Ecosyst Environ 89:23-40. doi:10.1016/ S0167-8809(01)00316-4

Liira J, Schmidt T, Aavik T et al (2008) Plant functional group composition and large-scale species richness in European agricultural landscapes. J Veg Sci 19:3-14. doi:10.3170/2007-8-18308

McCanny SJ, Cavers PB (1988) Spread of proso millet (Panicum miliaceum L.) in Ontario, Canada II: dispersal by combines. Weed Res 28:67-72. doi:10.1111/j.1365-3180.1988.tb00788.x

Marshall EJP (1989) Distribution patterns of plants associated with arable field edges. J Appl Ecol 26:247-257. doi:10.2307/2403665

Marshall EJP (2009) The impact of landscape structure and sown grass margin strips on weed assemblages in arable crops and their boundaries. Weed Res 49:107-115. doi:10.1111/j.1365-3180.2008. 00670.x

Marshall EJP, Smith BD (1987) Field margin flora and fauna; interaction with agriculture. In: Way JM, Greig-Smith PW (eds) Field margins. British Crop Protection Council, UK, pp 23-33

Marshall EJP, Brain P (1999) The horizontal movement of seeds in arable soil by different soil cultivation methods. J Appl Ecol 36:443-454. doi:10.1046/j.1365-2664.1999.00412.x

Marshall EJP, Moonen AC (2002) Field margins in northern Europe: their functions and interactions with agriculture. Agric Ecosyst Environ 89:5-21. doi:10.1016/S0167-8809(01)00315-2

Maxime F, Mollet JM, Papy F (1995) Aide au raisonnement de l'assolement en grande culture. Cahiers Agricultures 4:351-362

Mayor JP, Dessaint F (1998) Influence of weed management strategies on soil seedbank diversity. Weed Res 38:95-105

Mignolet C, Schott C, Benoît M (2007) Spatial dynamics of farming practices in the Seine basin: methods for agronomic approaches on a regional scale. Sci Total Environ 375:13-32. doi:10.1016/ j.scitotenv.2006.12.004

Morlon P, Trouche G (2005a) Nouveaux enjeux de la logistique dans les exploitations de grande culture. L'organisation spatiale des chantiers, une question dépassée ? Cahiers Agricultures 14:233239

Morlon P, Trouche G (2005b) Nouveaux enjeux de la logistique dans les exploitations de grandes cultures. La logistique, facteur de l'organisation spatiale des assolements en grande culture: quelques exemples. Cahiers Agricultures 14:305-311

Nathan R (2006) Long-distance dispersal of plants. Science 313:786-788

Norton L, Johnson P, Joys A, Stuart R, Chamberlain D, Feber R (2009) Consequences of organic and non-organic farming practices for field, farm and landscape complexity. Agric Ecosyst Environ 129:221-227. doi:10.1016/j.agee.2008.09.002

Oerke EC (2006) Crop losses to pests. J Agric Sci 144:31-43. doi:10.1017/S0021859605005708

Papy F (2001) Interdépendance des systèmes de culture dans l'exploitation agricole. In: Malézieux E, Trébuil G, Jaeger $M$ (eds) Modélisation des agro-écosystèmesagro écosystèmes et aide à la décision. Editions CIRAD-INRA, collection Repères, pp 51-74
Papy F, Attonaty JM, Laporte C, Soler LG (1988) Work organization simulation as a basis for farm management advice. Agric Syst 27:295-314. doi:10.1016/0308-521X(88)90037-6

Pelosi C, Goulard M, Balent G (2010) The spatial scale mismatch between ecological processes and agricultural management: do difficulties come from underlying theoretical frameworks? Agric Ecosys Environ. doi:10.1016/j.agee.2010.09.004

Perry JN, Gonzalez-Andujar JL (1993) Dispersal in a metapopulation neighbourhood model of an annual plant with a seedbank. J Ecol 81:453-463. doi:10.2307/2261524

Pessel FD, Lecomte J (2000) Towards an understanding of the dynamics of colza populations that have "escaped" from large-scale cultivation in an agricultural region. Oleagineux Corps Gras Lipides 7:324-328

Petit S, Boursault A, Le Guilloux M, Munier-Jolain N, Reboud X (2010) Weeds in agricultural landscapes: a review. Agron Sustain Dev 31:309-317. doi:10.1051/agro/2010020

Pivard S, Adamczyk K, Lecomte J, Lavigne C, Bouvier A, Deville A, Gouyon PH, Huet S (2008) Where do the feral oilseed rape populations come from? A large-scale study of their possible origin in a farmland area. J Appl Ecol 45:476-485. doi:10.1111/ j.1365-2664.2007.01358.x

Pleasant JMT, Schlather KJ (1994) Incidence of weed seed in cow manure and its importance as a weed source for cropland. Weed Technol 8:304-310

Poggio SL, Chaneton EJ, Ghersa CM (2010) Landscape complexity differentially affects alpha, beta, and gamma diversities of plants occurring in fencerows and crop fields. Biol Conserv 143:24772486. doi:10.1016/j.biocon.2010.06.014

Rew LJ, Theaker AJ, Froud-Williams RJ (1992) Nitrogen fertilizer misplacement and field boundaries. Asp Appl Biol 30:203-206

Rew LJ, Cussans GW (1997) Horizontal movement of seeds following tine and plough cultivation: implications for spatial dynamics of weed infestations. Weed Res 37:247-256. doi:10.1046/j.13653180.1997.d01-39.x

Rew LJ, Froud-Williams RJ, Boatman ND (1996) Dispersal of Bromus sterilis and Anthriscus sylvestris seed within arablefield margins. Agric Ecosyst Environ 59:107-114. doi:10.1016/0167-8809(96) 01038-9

Roger-Estrade J, Colbach N, Leterme P, Richard G, Caneill J (2001) Modelling vertical and lateral weed seed movements during mouldboard ploughing with a skim-coulter. Soil Till Res 63:3549. doi:10.1016/S0167-1987(01)00229-X

Römermann C, Tackenberg O, Poschlod P (2005) How to predict attachment potential of seeds to sheep and cattle coat from simple morphological seed traits. Oikos 110:219-230. doi:10.1111/j.00301299.2005.13911.x

Romero A, Chamorro L, Sans FX (2008) Weed diversity in crop edges and inner fields of organic and conventional dryland winter cereal crops in NE Spain. Agric Ecosyst Environ 124:97-104. doi:10.1016/ j.agee.2007.08.002

Roschewitz I, Gabriel D, Tscharntke T, Thies C (2005) The effects of landscape complexity on arable weed species diversity in organic and conventional farming. J Appl Ecol 42:873-882. doi:10.1111/ j.1365-2664.2005.01072.x

Rounsevell MDA, Annetts JE, Audsley E, Mayr T, Reginster I (2003) Modelling the spatial distribution of agricultural land use at the regional scale. Agric Ecosys Environ 95:465-479. doi:10.1016/ S0167-8809(02)00217-7

Rundolf M, Smith AG (2006) The effect of organic farming on butterfly diversity depends on landscape context. J. Appl. Ecol. 43: 1121-1127.

Schaller N, Aubry C, Martin P (2010) Modelling farmers' decisions of splitting agricultural plots at different time scales: a contribution for modelling landscape spatial configuration. Proceedings of "Agro2010 the XI ESA Congress", Montpellier, France, pp 879-880

Smith H, Feber RE, MacDonald DW (1994) The role of the wildflower seed mixtures in field margin restoration. In: Boatman ND (Ed) 
Field margin: integrating agriculture and conservation. Monograph 58, British Crop Protection Council, Warmick, pp 289-294

Storkey J, Moss SR, Cussans JW (2010) Using assembly theory to explain changes in a weed flora in response to agricultural intensification. Weed Sci 58:39-46. doi:10.1614/WS-09-096.1

Tamme R, Hiiesalu I, Laanisto L, Szava-Kovats R, Partel M (2010) Environmental heterogeneity, species diversity and co-existence at different spatial scales. J Veg Sci 21:796-801. doi:10.1111/ j.1654-1103.2010.01185.x

Tews J, Brose U, Grimm V, Tielbörger K, Wichmann MC, Schwager M, Jeltsch F (2004) Animal species diversity driven by habitat heterogeneity/diversity: the importance of keystone structures. J Biogeog 31:79-92

Thenail C (2002) Relationships between farm characteristics and the variation of the density of hedgerows at the level of a microregion of bocage landscape. Agric Syst 71:207-230. doi:10.1016/ S0308-521X(01)00048-8

Thenail C, Joannon A, Capitaine M, Souchère V, Mignolet C, Schermann N, di Pietro F, Pons Y, Gaucherel C, Viaud V, Baudry J (2009) The contribution of crop-rotation organization in farms to crop-mosaic patterning at local landscape scales. Agric Ecosyst Environ 131:207-219. doi:10.1016/j.agee.2009.01.015

Tscharntke T, Brandl R (2004) Plant-insect interactions in fragmented landscapes. Annu Rev Entomol 49:405-430. doi:10.1146/annurev. ento.49.061802.123339

Tsiouris S, Marshall EJP (1998) Observations on patterns of granular fertiliser deposition beside hedges and its likely effects on the botanical composition of field margins. Ann Appl Biol 132:115127. doi:10.1111/j.1744-7348.1998.tb05189.x

Vitalos M, Karrer G (2009) Dispersal of Ambrosia artemisiifolia seeds along roads: the contribution of traffic and mowing machines. Neobiota 8:53-60

Van Geert AF, Van Rossum F, Triest L (2010) Do linear landscape elements in farmland act as biological corridors for pollen dispersal? J Ecol 98:178-187. doi:10.1111/j.1365-2745.2009.01600.x von der Lippe M, Kowarik I (2007) Long-distance dispersal of plants by vehicles as a driver of plant invasions. Conserv Biol 21:986996. doi:10.1111/j.1523-1739.2007.00722.x

Wagner HH, Wildi O, Ewald KC (2000) Additive partitioning of plant species diversity in a agricultural mosaic landscape. Landscape Ecol 15:219-227. doi:10.1023/A:1008114117913

Wang TY, Chen HB, Reboud X, Darmency H (1997) Pollenmediated gene flow in an autogamous crop: foxtail millet (Setaria italica). Plant Breeding 116:579-583. doi:10.1111/j.1439-0523. 1997.tb02193.x

Wang JH, Kropff MJ, Lammert B, Christensen S, Hansen PK (2003) Using CA model to obtain insight into mechanism of plant population spread in a controllable system: annual weeds as an example. Ecol Model 166:277-286. doi:10.1016/S0304-3800 (03)00164-9

Weibull AC, Ostman O, Granqvist A (2003) Species richness in agroecosystems: the effect of landscape, habitat and farm management. Biodivers Conserv 12:1335-1355. doi:10.1023/ A: 1023617117780

West TM, Marshall EJP, Arnold GM (1997) Can sown field boundary strips reduce the ingress of aggressive field margin weeds? Proceedings of "Brighton crop protection conference: weeds". Brighton, UK, pp 985-990

Wilson PJ, Brain P (1991) Long-term stability of distribution of Alopecurus myosuroides Huds. within cereal fields. Weed Res 31:367-373. doi:10.1111/j.1365-3180.1991.tb01776.x

Wilson PJ, Aebischer NJ (1995) The distribution of dicotyledonous arable weeds in relation to distance from the field edge. J Appl Ecol 32:295-310. doi:10.2307/2405097

Woolcock JL, Cousens R (2000) A mathematical analysis of factors affecting the rate of spread of patches of annual weeds in an arable field. Weed Sci 48:27-34. doi:10.1614/0043-1745(2000)048 [0027:AMAOFA]2.0.CO;2

Zonneveld IS (1995) Vicinism and mass effect. J Veg Sci 5:441-444. doi: $10.2307 / 3236244$ 